\title{
Aktivitas Penghambatan Denaturasi Albumin dan Efek Anti-Inflamasi Campuran Ekstrak Herba Meniran, Daun Kelor, Daun Salam
}

\author{
Dian Ratih Laksmitawati*, Claudia Tiffani \\ Fakultas Farmasi Universitas Pancasila, Jl. Srengseng Sawah Jagakarsa, Jakarta \\ *Email korespondensi : dian.ratih@univpancasila.ac.id
}

(Submit 15/03/2019, Revisi 05/09/2019, Diterima 20/12/2019)

\begin{abstract}
Abstrak
Kombinasi herbal dalam satu formula memiliki keuntungan antara lain sinergisitas efek. Daun salam, daun kelor dan herba meniran dilaporkan memiliki aktivitas anti-inflamasi, namun dalam bentuk kombinasinya belum diketahui. Penelitian ini bertujuan untuk menetapkan aktivitas anti-inflamasi dari meniran (Phyllanthus niruri L.), daun kelor (Moringa oleifera Lamk) dan daun salam (Syzigium polyanthum (Wight) Walp) dalam bentuk tunggal dan kombinasinya secara in vitro dan in vivo. Metode : Metode pengujian aktivitas antiinflamasi in vitro menggunakan metode penghambatan denaturasi albumin sedangkan uji in vivo menggunakan metode edema pada telapak kaki tikus putih jantan. Ketiga daun dari tanaman tersebut masing-masing dibuat ekstrak dengan maserasi etanol $70 \%$. Sebagai sampel uji in vitro, dibuat 7 macam yaitu : ekstrak meniran (M) tunggal, ekstrak kelor $(\mathrm{K})$, tunggal ekstrak salam $(\mathrm{S})$ tunggal dan ekstrak kombinasi M:K:S dengan perbandingan $=1: 1: 1,2: 1: 1,1: 2: 1,1: 1: 2$. Ekstrak dengan aktivitas antiinflamasi in vitro tertinggi akan diujikan secara in vivo. Hasil dari pengujian in vitro menunjukkan persen inhibisi denaturasi albumin tertinggi pada kombinasi meniran : kelor : salam (1:2:1) sebesar $60,04 \% \pm 0,32$ dan secara in vivo diperoleh persen penghambatan edema kaki tikus yang diinduksi karagenan sebesar $9,06 \%$. Aktivitas penghambatan denaturasi albumin $\mathrm{Na}$ diklofenak sebagai kontrol adalah $84,06 \%$ dan secara invivo sebesar $41,21 \%$. Aktivitas anti-inflamasi in vivo ektrak tunggal meniran sebesar $19,59 \%$. Kombinasi ekstrak daun meniran, kelor dan salam dengan perbandingan 1:2:1 mempunyai aktivitas antiinflamasi melalui metode penghambatan denaturasi albumin yang cukup besar $(60,04 \%)$, namun aktivitas penghambatan radang kaki tikus tidak sebaik in vitronya $(9,06 \%)$.
\end{abstract}

Kata kunci: anti-inflamasi, Phyllanthus niruri, Moringa oleifera, Syzigium polyanthum, denaturasi albumin

\section{Outline}

- Pendahuluan

- Metode

- Hasil dan Pembahasan

- Kesimpulan

- Daftar Pustaka 


\section{Pendahuluan}

Inflamasi adalah respon protektif normal terhadap jaringan yang disebabkan oleh trauma fisik, zat kimia yang merusak atau zat-zat mikroorganisme. Inflamasi dicetuskan oleh pelepasan mediator kimiawi dari jaringan yang rusak dan migrasi sel yang kemudian akan menyebabkan serangkaian proses yang dimulai dari timbulnya rubor (kemerahan), panas (kalor), dolor (nyeri), pembengkakan (tumor), dan sampai terjadinya gangguan fungsi organ yang mengalami cedera (fungsio laesa). Beberapa penyakit didasari oleh inflamasi mulai dari penyakit yang tergolong ringan hingga penyakit yang tergolong berat. Obat-obatan anti-inflamasi terdiri dari dua golongan yaitu golongan steroid dan golongan Non-steroid. Penggunaan kedua golongan ini apabila dikonsumsi dalam jangka panjang dapat menyebabkan efek samping yang tidak diinginkan seperti gangguan pada lambung. Untuk mengatasi efek samping tersebut maka diperlukan pengobatan alternatif lain yang dapat mencegah terjadinya inflamasi sistemik. Salah satu pengobatan alternatif inflamasi yaitu dengan memanfaatkan tanaman herbal.

Beberapa penelitian telah dilakukan oleh beberapa peneliti untuk mengetahui aktivitas Daun salam (Syzygium polyanthum (Wight) Walp.), daun kelor (Moringa oleifera L.) dan herba meniran (Phyllanyhus niruri L.) baik secara in vitro maupun secara in vivo. Berdasarkan hasil penelitian terdahulu dari kombinasi ekstrak air daun salam dan daun sambiloto menunjukkan efek anti-inflamasi pada tikus edema dengan induksi karagenan ${ }^{1}$. Ekstrak etanol daun kelor (Moringa oleifera Lamk) menunjukkan penghambatan volume edema kaki tikus yang diinduksi karagenan signifikan pada dosis 200 dan $500 \mathrm{mg} / \mathrm{kgBB}{ }^{2}$. Sedangkan herba meniran (Phyllanyhus niruri L.) dilaporkan mempunyai aktivitas anti-inflamasi pada dosis 100,200,400 mg/kgbb signifikan dalam mengurangi inflamasi pada kaki tikus yang diinduksi karagenan $1 \%{ }^{3}$. Pada paparan diatas diketahui bahwa ketiga tanaman yaitu herba meniran, daun kelor dan daun salam mempunyai khasiat inflamasi.

Dalam bentuk tunggal atau kombinasi dengan bahan lain kekuatan aktivitas antiinflamasi dalam bentuk kombinasi dari ketiganya belum diketahui. Sediaan poliherbal yang berisi kombinasi herbal dalam satu bentuk sediaan memiliki beberapa keuntungan diantaranya menimbulkan efek saling sinergis mengurangi efek samping, dan memberi khasiat tambahan yang tidak dimiliki herbal lain. Untuk mengetahui kekuatan efek antiinflamasi ketiga herbal tersebut maka pada penelitian ini akan dilakukan pengujian secara in vitro dengan metode peghambatan denaturasi albumin. Terhadap ekstrak tunggal dan kombinasi yang dibuat tiga kombinasi antara ekstrak herba meniran, daun kelor, dan daun salam sehingga aktivitas anti-inflamasi dapat diketahui. Ekstrak atau kombinasi ekstrak yang memiliki aktivitas anti-inflamasi terpilih selanjutnya akan diteruskan melalui uji in vivo dengan metode uji radang pada telapak kaki tikus yang diinduksi dengan menggunakan karagenan.

\section{Metode}

\section{A. Bahan}

Sampel : herba meniran (Phylanthus niruri), daun kelor (Moringa oleifera L.), dan daun salam (Syzygium polyanthum) yang diperoleh dari Balitro Pascapanen Bogor dan dideterminasi di Herbarium Bogoriense, Pusat Penelitian dan Pengembangan Biologi, LIPI Cibinong, Jawa Barat. Serbuk sampel diekstraksi menggunakan etanol $70 \%$. 
Bahan kimia untuk uji in vitro: Bovine Serum Albumin (BSA) Sigma Aldrich, Tris base, Tris buffer saline, Natrium diklofenak, dimetilsulfoksida (DMSO), aquadest

Bahan untuk uji in vivo: karagenan dan hewan coba yaitu tikus putih jantan (galur Sprague Dawley) yang diperoleh dari Laboratorium Ruminansia dan Satwa Harapan Fakultas Peternakan Institut Pertanian Bogor (IPB), berat 150-200 gram usia 2-3 bulan sebanyak 25 ekor diadaptasikan didalam lingkungan Laboratorium Farmakologi \& Toksikologi Fakultas Farmasi Universitas Pancasila selama 1 minggu. Selama adaptasi, tikus diberi pakan dan minuman standar ad libitum.

\section{B. Metode}

1. Persiapan Sampel

\section{Pembuatan Perbandingan Kombinasi Ekstrak Meniran:Kelor:Salam}

Dibuat perbandingan ekstrak Meniran:Kelor:Salam (M:K:S) dengan konsentrasi akhir $300 \mathrm{bpj}$, sebagai berikut : sampel $1 \mathrm{M}: \mathrm{K}: \mathrm{S}=1: 0: 0$; sampel $2 \mathrm{M}: \mathrm{K}: \mathrm{S}=0: 1: 0$; Sampel 3 $\mathrm{M}: \mathrm{K}: \mathrm{S}=0: 0: 1$; sampel $4 \mathrm{M}: \mathrm{K}: \mathrm{S}=1: 1: 1$; sampel $5 \mathrm{M}: \mathrm{K}: \mathrm{S}=2: 1: 1$; sampel $6 \mathrm{M}: \mathrm{K}: \mathrm{S}=$ $1: 2: 1$; sampel $7 \mathrm{M}: \mathrm{K}: \mathrm{S}=1: 1: 2$.

\section{Pengujian Aktivitas Anti-inflamasi in vitro ${ }^{4}$}

Sebanyak $500 \mu \mathrm{l}$ dari larutan sampel 1-7/larutan kontrol positif Na diklofenak masingmasing dengan konsentrasi 300 bpj ditambahkan larutan BSA 0,15\% dalam Tris Buffer Saline (TBS) ad $5 \mathrm{~mL}$ dan di inkubasi pada suhu $25^{\circ} \mathrm{C}$ selama 30 menit. Campuran kemudian dipanaskan selama 5 menit pada suhu $70^{\circ} \mathrm{C}$ kemudian didinginkan dengan cara di rendam dalam wadah berisi air kurang lebih 10 menit. Setelah dingin larutan divortex dan dilakukan pengukuran absorbansi dengan menggunakan instrument spektrofotometer UV-visible pada panjang gelombang $660 \mathrm{~nm}$. Pengujian dilakukan sebanyak tiga kali pengulangan. Persentase penghambatan denaturasi protein diukur dengan menggunakan rumus sebagai berikut :

$\%$ inhibisi $=\frac{\text { absorbansi } \text { kontrol negatif }- \text { absorbansi larutan } u j i}{\text { absorbansi } \text { kontrol negatif }} \times 100 \%$

\section{Pengujian aktivitas anti-inflamasi in vivo}

Sebanyak 25 ekor tikus diambil secara acak dan dibagi menjadi empat kelompok, masing-masing kelompok terdiri dari 5 ekor.

Kelompok 1 : tikus normal tanpa perlakuan

Kelompok 2 : tikus kontrol (-) tanpa pengobatan namun diberi perlakuan induksi edema Kelompok 3 : tikus kontrol (+)natrium diklofenak dosis $9 \mathrm{mg} / \mathrm{kgBB}$ dan diinduksi edema Kelompok 4 : tikus yang diberi sampel ekstrak kombinasi terpilih (yang mempunyai persentase inhibisi denaturasi albumin tertinggi) dosis $200 \mathrm{mg} / \mathrm{kgBB}$ kemudian diinduksi edema

Semua kelompok diberikan perlakuan sediaan uji per oral natrium diklofenak dosis $9 \mathrm{mg} / \mathrm{kgBB}$ atau sampel ekstrak terpilih dosis $200 \mathrm{mg} / \mathrm{kgBB}$ atau CMC Na 0,05\%. Tiga puluh menit setelah pemberian sediaan uji, telapak kaki tikus masing-masing kelompok kecuali pada kelompok normal, disuntikkan karagenan 1\% secara subplantar. Kemudian volume pembengkakan telapak kaki tikus diukur menggunakan alat pletismometer pada jam ke-1, 2, 3,4 dan 5 terhitung setelah penginduksian karagenan 
1\%. Persentase penghambatan edema ditetapkan melalui perhitungan Daerah di bawah Kurva (DDK) dan dengan rumus :

Keterangan :

$$
\mathrm{DDK}_{0-5} \quad=\frac{(v n-1+v n)(t n-t n-1)}{2}
$$

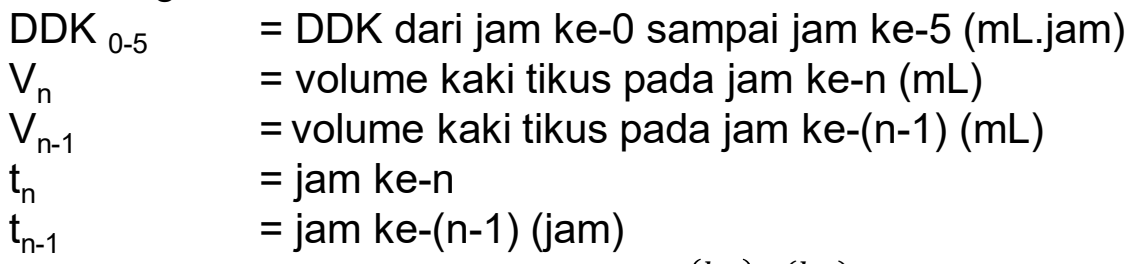

Persentase penghambatan edema $=\frac{(k-)-(k+)}{k} \times 100 \%$

\section{Hasil dan Pembahasan}

\section{A. Hasil}

1. Penghambatan Denaturasi Albumin

Berdasarkan hasil uji aktivitas anti-inflamasi secara in vitro menggunakan metode denaturasi albumin pada kondisi optimum $\mathrm{pH}$ 5,8 dengan waktu inkubasi 5 menit didapatkan hasil ekstrak tunggal herba meniran, daun kelor, daun salam memiliki ratarata persen penghambatan denaturasi albumin sebesar berturut-turut $34.13 \%, 43.44 \%$ dan 40.70\%. Ekstrak kombinasi M:K:S 1:1:1 , 2:1:1, 1:2:1, 1:1:2 memberikan hambatan denaturasi albumin sebesar berturut-turut $47.19 \%$. 43.02\%. 60.04\%. 59.73\%, sedangkan hambatan denaturasi oleh natrium diklofenak adalah 84,06\%Berdasarkan hasil persen penghambatan dari ketujuh perbandingan didapatkan hasil M:K:S ke-6 memiliki aktivitas anti-inflamasi secara denaturasi albumin tertinggi maka M:K:S ke-6 merupakan kombinasi terpilih yang akan dilanjutkan uji in vivo. Hasil Uji penghambatan denaturasi albumin dapat dilihat pada Tabel 1.

Tabel 1. Persentase Penghambatan Denaturasi Albumin

\begin{tabular}{|c|c|}
\hline Kelompok @ kosentrasi 300 bpj & rata-rata \% inhibisi \\
\hline kontrol negatif & 0,00 \\
\hline Natrium Diklofenak & $84,06 \pm 0,15$ \\
\hline$M: K: S=1: 0: 0$ & $34,13 \pm 0,65^{a}$ \\
\hline$M: K: S=0: 1: 0$ & $43,44 \pm 0,61^{b}$ \\
\hline M:K:S = 0:0:1 & $40,70 \pm 0,26^{c}$ \\
\hline$M: K: S=1: 1: 1$ & $47.19 \pm 0,24^{d}$ \\
\hline M:K:S = 2:1:1 & $43.02 \pm 1,11^{b}$ \\
\hline M:K:S = 1:2:1 & $60,04 \pm 0,32^{\mathrm{e}}$ \\
\hline$M: K: S=1: 1: 2$ & $59,73 \pm 0,45^{e}$ \\
\hline
\end{tabular}

\section{Penghambatan Edema Kaki Tikus}

Gambar 1, memperlihatkan profil volume edema kaki tikus percobaan. Profil edema kaki tikus dengan zat penginduksi karagenan dapat dilihat pada kelompok kontrol negatif, yaitu kelompok tanpa pemberian zat uji. Dari Gambar 1 terlihat bahwa pada jam ke-1 setelah diinduksi karagenan $1 \%$ secara subplantar volume kaki tikus mengalami pembengkakan, kemudian pada jam ke-2 mengalami penurunan dan kembali meningkat pada jam ke-3 yang merupakan respon bengkak akibat induksi karagenan. Volume kaki tikus mulai mengalami penurunan pada jam ke-4. 
Penetapan persentase penghambatan edema dilakukan melalui perhitungan nilai ratarata Daerah Di bawah Kurva dari jam ke 0 sampai ke $5\left(\mathrm{DDK}_{0-5}\right)$ dan di dapatkan hasil seperti pada Tabel 2.

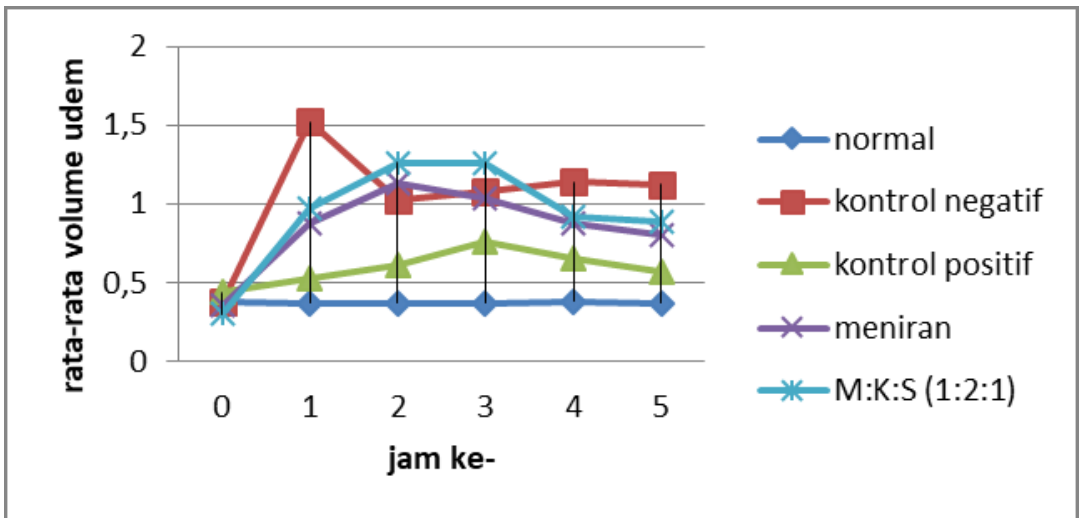

Gambar 1. Kurva hubungan antara rata-rata volume kaki tikus terhadap waktu

Tabel 2. Persen penghambatan edema

Kelompok

\section{Normal}

Kontrol negatif

Kontrol Positif

(Na. Diklofenak) $100 \mathrm{mg} / \mathrm{kgBB}$

Ekstrak Meniran $200 \mathrm{mg} / \mathrm{kgBB}$

Ekstrak M:K:S (1:2:1) 200 mg/kgBB
Rata-rata DDK 0 (mL.jam)

\section{$0.36 \pm 0,06$}

$5,63 \pm 0,57$

$3,31 \pm 1,15$

$4,53 \pm 0,61$

$5,12 \pm 0,5$
$\%$ penghambatan edema

$0,00^{\mathrm{a}}$

$41,21^{b}$

$19,54^{c}$

$9,06^{\mathrm{ac}}$

Keterangan : Huruf superskrip yang berbeda menandakan perbedaan bermakna ( $p$ $0,05 \%$, Anova, LSD)

Berdasarkan hasil perhitungan persen penghambatan edema didapatkan hasil pada kelompok kontrol positif memiliki daya hambat sebesar $41,21 \%$, pada ekstrak tunggal meniran memiliki daya hambat sebesar $19,54 \%$ lebih besar dibandingkan dengan ekstrak M:K:S dengan komposisi 1:2:1 sebesar 9,06\%.

\section{B. Pembahasan}

Lebih dari $70 \%$ populasi dunia mengandalkan pengobatan herbal sebagai bagian dari perawatan kesehatan yang utama. Di berbagai wilayah dan budaya yang berbeda, produk herbal digunakan dalam bentuk tunggal, kombinasi herbal dengan herbal dan kombinasi herbal dengan obat (36) sehingga pada penelitian ini dilakukan uji aktivitas anti-inflamasi antara herba meniran, daun kelor dan daun salam baik dalam bentuk tunggal maupun yang dikombinasi secara in vitro dan in vivo. Metode in vitro dimaksudkan untuk skrining kombinasi ekstrak yang memiliki aktivitas penghambatan denaturasi albumin paling tinggi. Ekstrak dengan nilai penghambatan denaturasi albumin tertinggi akan diujikan secara in vivo menggunakan metode induksi edema kaki tikus oleh karagenan.

Metode penghambatan denaturasi albumin dapat digunakan skrining aktivitas antiinflamasi sebelum dilakukan uji anti-inflamasi menggunakan hewan coba seperti pada penelitian oleh LAD Williams $(2008)^{4}$. Ketika BSA dipanaskan maka akan terdenaturasi. 
Denaturasi albumin bertindak sebagai antigen yang terlibat pada reaksi imun seperti hypersensitive tipe III, serum sickness, glomerulonephritis, artritis rematoid, lupus eritematosus yang merupakan penyakit autoimun berbasis inflamasi. Suatu agen yang dapat menghambat denaturasi albumin atau menstabilkan albumin $>20 \%$ maka dapat dipertimbangkan mempunyai sifat anti-inflamasi dan dapat dilanjutkan pada pengujian anti-inflamasi lanjutan ${ }^{4-6}$. Dari ke 7 kombinasi ekstrak yang terdiri dari 3 varian ekstrak tunggal dan 4 varian kombinasi kesemuanya menunjukkan penghambatan denaturasi albumin berkisar antara 34,13 $\pm 0,65 \%$ sampai dengan 60,04 $\pm 0,32 \%$ (ekstrak kombinasi $\mathrm{M}: \mathrm{K}: \mathrm{S}=1: 1: 2$ ), sementara penghambatan denaturasi albumin Na diklofenak adalah $84,06 \pm 0,15 \%$.

Ekstrak yang terpilih yaitu ekstrak kombinasi $\mathrm{M}: \mathrm{K}: \mathrm{S}=1: 1: 2$, diuji secara invivo kepada tikus yang diinduksi edema pada telapak kaki belakangnya dengan karagenan. Hasil menunjukkan bahwa persentase penghambatan edema kombinasi esktrak tersebut termasuk bernilai rendah yaitu hanya $9,06 \%$ dan tidak signifikan dibandingkan dengan kelompok yang tidak diberikan terapi. Beberapa kemungkinan penyebab tidak liniernya hasil percobaan in vitro dan in vivo adalah adanya hambatan farmakokinetika ekstrak bila diberikan secara in vivo meliputi absorbsi, distribusi, metabolism dan ekskresi yang tidak didapatkan ketika melakukan pengujian in vitro. Kemungkinan lain adalah karena tidak spesifiknya uji penghambatan denaturasi albumin. William menuliskan bahwa suatu senyawa yang mempunyai potensi penghambatan denaturasi albumin dapat dimasukkan ke dalam senyawa yang memiliki aktivitas biologi seperti antioksidan, antioksidan, anticancer, imunomodulasi dan lainnya ${ }^{4}$, tidak hanya sebagai antiinflamasi.

\section{Kesimpulan}

Ekstrak herba meniran, daun kelor dan daun salam dalam bentuk tunggal dan kombinasinya mempunyai kemampuan menghambat denaturasi albumin lebih dari $20 \%$. Ekstrak yang mempunyai kemampuan penghambatan denaturasi albumin tertinggi $(60,04 \%)$ adalah ekstrak M:K:S $=1: 1: 2$. Namun kombinasi ini hanya mampu menghambat edema kaki tikus sebesar $9,06 \%$.

\section{Daftar Pustaka}

1. Mustafa RH, Hadisoewignyo L, Ervina M, Soegianto L. Optimizing Combination of Sambiloto Herbal Water Fraction and Salam Leaf Water Fraction As AntiInflammation.

2. Pal G, Singh GP, Garg R, Sharma SK. Anti-Inflammatory Evaluation of Leaf Extract of Moringa Oleifera. J Pharm Sci Innov. 2012;1(1):22-4.

3. Begum T, Hossain A, Tuhin RH, Sharma M, Sohanur Rahman M, Mostofa R, et al. Evaluation of anti-inflammatory and gastric anti-ulcer activity of Phyllanthus niruri L. (Euphorbiaceae) leaves in experimental rats. BMC Complement Altern Med. 2017;17(1).

4. Williams LAD, O'Connar A, Latore L, Dennis O, Ringer S, Whittaker JA, et al. The in vitro anti-denaturation effects induced by natural products and non-steroidal compounds in heat treated (Immunogenic) bovine serum albumin is proposed as a screening assay for the detection of anti-inflammatory compounds, without the use of animals. West Indian Med J. 2008;57(4):327-31. 
5. Tatti PN, Anitha S, Shashidhara S, Deepak M, Bidari S. Evaluation of in-Vitro AntiDenaturation Activity of Isolated Compound of Butea Monosperma Bark . Pharma Sci Monit. 2012;3(4):2314-20.

6. Bailey-shaw YA, Williams LAD, Green CE, Rodney S, Smith AM, Division D, et al. Research Article In-Vitro Evaluation of the Anti-Inflammatory Potential of Selected Jamaican Plant Extracts using the Bovine Serum Albumin Protein Denaturation Assay. 1. Int J Pharm Sci. 2017;47(27):145-53. 